\title{
STUDI PEMETAAN DAERAH GENANGAN BANJIR DAS SEI SIKAMBING DENGAN SISTEM INFORMASI GEOGRAFIS
}

\author{
Asril Zevri \\ Balai Wilayah Sungai (BWS) Sumatera II Dirjen SDA Kemenpupr \\ Jl. Jend Besar Dr. A. Nasution No. 30 Pkl. Mashur Telp. (061) 7881522 - 7861533 \\ Fax (061) 7861455 Kode Pos 20143 Medan \\ E-mail: $\underline{\text { Asrilzevri19@gmail.com }}$
}

DOI: http://dx.doi.org/10.29103/tj.v9i2.233

(Received: June 2019 / Revised: July 2019 / Accepted: August 2019)

\begin{abstract}
Abstrak
Daerah Aliran Sungai Sei Sikambing merupakan salah satu Sub Das Sungai Deli yang berperan penting terhadap kebutuhan air di Kota Medan. Curah hujan dengan intensitas yang tinggi didukung dengan perubahan tata guna lahan menimbulkan banjir yang mencapai $0,6 \mathrm{~m}$ s/d $1 \mathrm{~m}$ dari tebing sungai. Tujuan dari penelitian ini untuk melakukan pemetaan daerah genangan banjir DAS Sungai Sei Kambing sebagai informasi kepada masyarakat dalam usaha mitigasi bencana. Lingkup kegiatan dari penelitian ini yaitu menganalisa curah hujan harian maksimum dengan kala ulang 2 s/d 100 tahun, menganalisa debit banjir dengan kala ulang 2 s/d 100, menganalisa tinggi muka air banjir dengan software HECRAS, dan pemetaan secara spasial daerah genangan banjir dengan SIG. Hasil penelitian menunjukan debit banjir kala ulang DAS Sikambing dengan periode kala ulang 25 tahun $211,94 \mathrm{~m}^{3} / \mathrm{det}$ menimbulkan tinggi muka air banjir DAS Sikambing berada diantara $1,7 \mathrm{~m} \mathrm{~s} / \mathrm{d} \mathrm{3,7} \mathrm{m}$. Daerah genangan banjir DAS Sikambing mencapai luasan $1,19 \mathrm{Km}^{2}$ yang mengakibatkan dampak banjir terhadap 5 kecamatan di Kota Medan yaitu Kecamatan Medan Selayang, Medan Sunggal, Medan Petisah, Medan Helvetia, dan Medan Barat.
\end{abstract}

Kata Kunci: Debit banjir, daerah genangan banjir, hecras, SIG, kota Medan

\begin{abstract}
Sei Sikambing River Basin is one of the Sub Das of Deli River which has an important role in water requirement in Medan City. Rainfall with high intensity is supported by changes in land use causing floods which reach $0.6 \mathrm{~m}$ to $1 \mathrm{~m}$ from river banks. The purpose of this study was to map the Sei Kambing River basin flood inundation area as information to the public in disaster mitigation efforts. The scope of this research is to analyze the maximum daily rainfall with a return period of 2 to 100 years, analyze flood discharge with a return period of 2 to 100, analyze flood water levels with HECRAS software, and spatially map flood inundation areas with GIS. The results showed that the return flood rate of the Sikambing watershed with a 25year return period of $211.94 \mathrm{~m}^{3} / \mathrm{s}$ caused the flood level of the Sikambing watershed to be between $1.7 \mathrm{~m}$ to $3.7 \mathrm{~m}$. The Sikambing watershed flood inundation area reached an area of $1.19 \mathrm{Km}^{2}$ which resulted in the impact of flooding on $5 \mathrm{sub}-$ districts in Medan, namely Medan Selayang District, Medan Sunggal, Medan Petisah, Medan Helvetia, and West Medan.
\end{abstract}

Keywords: Flood discharge, inundation area, hecras, GIS, Medan city

Studi Pemetaan Daerah Genangan Banjir Das Sei Sikambing Dengan Sistem Informasi 


\section{Latar Belakang}

Intensitas curah hujan yang sangat tinggi disertai dengan perubahan tata guna lahan yang sangat signifikan di DAS Sikambing mengakibatkan aliran limpasan permukaan seluruhnya mengalir menuju badan sungai. Kondisi badan sungai yang mengalami pendangkalan akibat sedimentasi mengakibatkan permukaan air sungai meningkat (overflow) dan menggenangi dataran pemukiman di sekitar badan sungai.

Dataran banjir yang menggenangi daerah pemukiman mengakibatkan dampak yang merugikan bagi masyarakat khususnya di sekitar Kota Medan. Tinggi muka air banjir dapat mencapai $0.5 \mathrm{~m} \mathrm{~s} / \mathrm{d} 1 \mathrm{~m}$ dari tebing sungai (BPBD Kota Medan, 2018). Dataran banjir merupakan daerah rawan banjir yang dapat diklasifikasi berdasarkan kala ulang banjirnya semakin besar kala ulang banjir maka semakin besar dataran banjirnya. Dataran banjir di sekitar bantaran sungai yang masuk dalam daerah genangan pada debit banjir tahunan Q100 merupakan daerah rawan banjir yang tertinggi (Zevri, 2014)

Salah satu alternative metode pengendalian banjir secara non struktural yaitu dengan merencanakan pemetaan daerah genangan banjir sebagai alat informasi dalam mitigasi bencana (Marlena, 2010). Tingkat resiko di daerah genangan banjir bervariasi tergantung ketinggian permukaan tanah setempat dengan menggunakan peta kontur ketinggian permukaan tanah serta melalui analisis hidrologi dan hidrolika dapat ditentukan tinggi muka air banjir dengan luas dataran banjir. Integrasi antara hasil tinggi muka air banjir dengan dataran banjir dapat disajikan dalam bentuk pemetaan secara spasial dengan Sistem Informasi Geografis yang menghasilkan peta daerah genangan banjir.

\section{Metode Penelitian}

Lokasi penelitian berada di DAS Sei Sikambing dengan luas tangkapan air mencapai $42,55 \mathrm{Km}^{2}$ dengan panjang sungai utama $18,73 \mathrm{Km}$. Luas catchment area DAS Sei Sikambing mencakup 3 Kecamatan yang berada di Kota Medan dan rentan terhadap potensi banjir yaitu Medan Selayang, Medan Baru, dan Medan Petisah. Peta DAS Sei Sikambing ditampilkan pada Gambar 1.

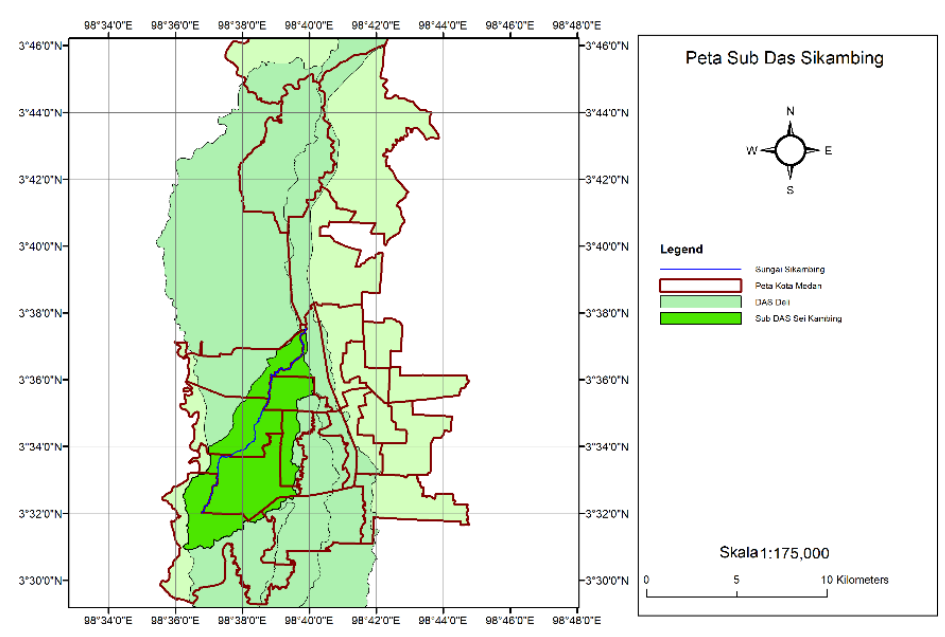

Gambar 1 Peta Das Sei Sikambing 
Penelitian dilakukan secara eksploratif, kuantitatif, dan kualitatif. Artinya data-data penelitian diperoleh secara kuantitatif menggunakan persamaanpersamaan yang relevan dan hasilnya dijelaskan secara kualitatif. Kemudian kesimpulan diambil secara induktif yang artinya poin-poin pengamatan lapangan dan analisa data akan menghasilkan daerah genangan banjir.

\subsection{Pengumpulan data}

Data-data yang diperlukan dalam penelitian ini terdiri dari data primer dan sekunder di mana data primer yang diperoleh dari hasil pengamatan langsung di lapangan seperti data pengukuran penampang sungai baik itu long dan cross section sungai. Data sekunder diperoleh dari hasil laporan terdahulu dengan pengamatan data yang dilakukan oleh instansi terkait seperti data curah hujan, peta daerah aliran sungai, data tata guna lahan, dan peta administrative Kota Medan. Kombinasi dari kedua data tersebut menjadi dasar dalam penelitian ini.

\subsection{Analisa Hidrologi}

Prosedur atau tahapan dalam analisa hidrologi dalam penelitian ini dimulai dengan analisa curah hujan rata-rata kawasan, curah hujan kala ulang 2 s/d 100 tahun, dan debit banjir kala ulang 2 s/d 100 tahun. Analisa curah hujan rata-rata harian maksimum kawasan DAS diperoleh dengan menggunakan metode polygon thiessen berdasarkan data curah hujan harian maksimum 10 tahun dari 3 stasiun penakar curah hujan yaitu Tanjung Selamat, BMKG Wilayah I, dan Helvetia. Hasil analisa curah hujan rata-rata harian maksimum kawasan DAS digunakan untuk memprediksi curah hujan kala ulang 2 s/d 100 tahun dengan pendekatan metode statistik probabilistik yaitu normal, log normal, log person, dan gumbel.

Uji distribusi terhadap metode statistik probabilistik digunakan sebagai koreksi terhadap tingkat kepercayaan antara data curah hujan harian maksimum dengan hasil prediksi curah hujan kala ulang sehingga dari keempat metode akan diperoleh satu metode yang memberikan hasil dengan tingkat kepercayaaan yang mendekati dengan hasil di lapangan. Metode yang terpilih dalam analisa curah hujan kala ulang digunakan dalam analisa debit banjir kala ulang dengan metode Hidrograf Satuan Sintetis Nakayasu dengan data pendukung seperti panjang sungai, luas daerah aliran sungai dan koefisien limpasan. Prinsip metode Hidrograf Satuan Sintetis Nakayasu dianalisa dengan limpasan langsung akibat curah hujan berdasarkan intensitas curah hujan jam-jaman sehingga menghasilkan debit jam-jaman kala ulang.

\subsection{Analisa Tinggi Muka Air Banjir dengan Software HECRAS}

Tinggi muka air banjir penampang sungai Sei Sikambing diperoleh dengan mengunakan software HECRAS yang didukung dengan beberapa data seperti data debit banjir kala ulang jam-jaman, penampang memanjang dan melintang sungai, dan dengan kemiringan dasar sungai. Hasil simulasi memberikan informasi potensi elevasi muka air banjir di tiap penampang sungai berdasarkan elevasi dasar penampang sungai dan tebing sungai sehingga diperoleh tinggi muka air banjir maksimum berdasarkan debit banjir kala ulang (Ginting, 2010). 


\subsection{Analisa Pemetaan Daerah Genangan Banjir Dengan Sistem Informasi Geografis}

Pemetaan daerah genangan banjir DAS Sei Kambing dilakukan berdasarkan integrasi hasil simulasi tinggi muka air banjir dengan Software HECRAS, peta daerah aliran sungai, dan peta administrative Kota Medan. Integrasi antara kedua layer akan menghasilkan potensi daerah genangan banjir berdasarkan debit banjir kala ulang sehingga wilayah yang terkena dampak banjir dapat diprediksi (Cahyono, 2016).

\section{Hasil dan Pembahasan}

\subsection{Analisa Hidrologi}

Analisa Hidrologi terdiri dari analisa curah hujan harian maksimum rata-rata di sekitar DAS Sei Sikambing, curah hujan kala ulang 2 s/d 100 tahun, Uji distribusi curah hujan kala ulang, dan debit banjir kala ulang 2 s/d 100 tahun. Analisa curah hujan harian maksimum rata-rata di sekitar DAS Sei Sikambing bertujuan untuk mengetahui besar curah hujan harian maksimum yang telah terjadi dalam kurun waktu lebih kurang 10 tahun dan menjadi dasar dalam analisa penentuan debit banjir kala ulang. Pengambilan data curah hujan harian maksimum diperoleh dari 3 stasiun penakar curah hujan yang mewakili bagian hulu, tengah, dan hilir DAS Sikambing. Stasiun penakar curah hujan yang mewakili di bagian DAS yaitu Stasiun penakar curah hujan Helvetia di bagian hilir, BMKG Wilayah I bagian tengah, dan Tanjung Selamat di bagian hulu. Data curah hujan harian maksimum selama kurun waktu 10 tahun dari 3 stasiun penakar curah hujan ditampilkan pada Tabel 1.

Tabel 1 Data curah hujan harian maksimum 10 tahun dari 3 stasiun penakar curah hujan Das Sei Kambing

\begin{tabular}{cccc}
\hline No & $\begin{array}{c}\text { Tjg } \\
\text { Selamat }\end{array}$ & BMKG Wil I & Helvetia \\
\hline 1 & 185 & 165 & 58 \\
\hline 2 & 152 & 135 & 47 \\
\hline 3 & 119 & 111 & 45 \\
\hline 4 & 110 & 103 & 43 \\
\hline 5 & 107 & 98 & 42 \\
\hline 6 & 99 & 90 & 41 \\
\hline 7 & 91 & 89 & 40 \\
\hline 8 & 81 & 84 & 38 \\
\hline 9 & 75 & 83 & 36 \\
\hline 10 & 45 & 71 & 36 \\
\hline
\end{tabular}

Hasil analisa curah hujan harian maksimum rata-rata DAS Sei Sikambing dilakukan dengan metode Polygon Thiessen yang ditentukan dengan adanya pengaruh luas tangkapan stasiun curah hujan di sekitar DAS Sei Sikambing yang ditampilkan pada Gambar 2. 


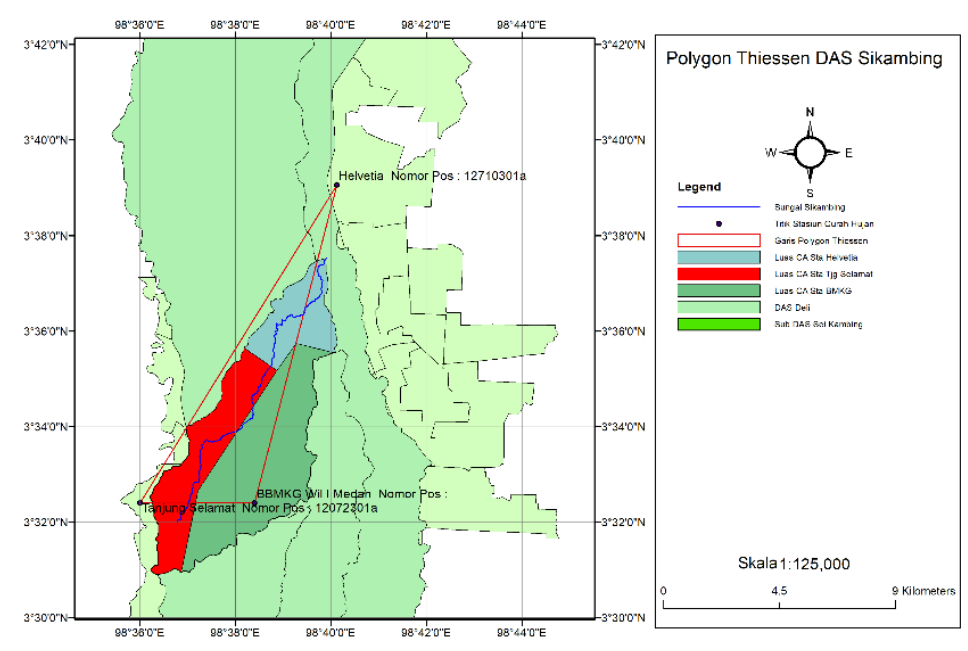

Gambar 2 Polygon Thiessen Das Sei Sikambing

Hasil dari metode polygon thiessen memberikan luas pengaruh stasiun curah hujan terhadap DAS Sikambing yang ditampilkan pada Tabel 2.

Tabel 2 Luas pengaruh stasiun curah hujan Das Sei Sikambing

\begin{tabular}{ccc}
\hline Stasiun & $\begin{array}{c}\text { Luas } \\
\left(\mathbf{k m}^{\mathbf{2}}\right)\end{array}$ & Faktor Thiessen \\
\hline Tjg Selamat & 12.62 & 0.30 \\
\hline BMKG Wil I & 22.21 & 0.52 \\
\hline Helvetia & 7.71 & 0.18 \\
\hline
\end{tabular}

Luas pengaruh stasiun curah hujan yang terdiri dari 3 stasiun sebagai perwakilan dari bagian sungai di hulu, tengah, dan hilir menjelaskan pengaruh stasiun curah hujan di bagian tengah yaitu Stasiun Curah Hujan BMKG Wilayah I memberikan pengaruh yang besar terhadap debit aliran di Daerah Aliran Sungai Sei Sikambing. Hasil analisa curah hujan harian maksimum rata-rata DAS Sei Sikambing dari 3 stasiun penakar curah hujan ditampilkan pada Tabel 3.

Tabel 3 Hasil analisa curah hujan harian maksimum rata-rata Das Sei Sikambing

\begin{tabular}{cccccccc}
\hline No & $\begin{array}{c}\text { Tjg } \\
\text { Selamat }\end{array}$ & $\begin{array}{c}\text { Faktor } \\
\text { Thiessen }\end{array}$ & $\begin{array}{c}\text { BKMG } \\
\text { Wil I }\end{array}$ & $\begin{array}{c}\text { Faktor } \\
\text { Thiessen }\end{array}$ & Helvetia & $\begin{array}{c}\text { Faktor } \\
\text { Thiessen }\end{array}$ & $\begin{array}{c}\text { Rata- } \\
\text { Rata }\end{array}$ \\
\hline 1 & 185 & 0,30 & 165 & 0,52 & 58 & 0,18 & 151,50 \\
\hline 2 & 152 & 0,30 & 135 & 0,52 & 47 & 0,18 & 124,09 \\
\hline 3 & 119 & 0,30 & 111 & 0,52 & 45 & 0,18 & 101,43 \\
\hline 4 & 110 & 0,30 & 103 & 0,52 & 43 & 0,18 & 94,11 \\
\hline 5 & 107 & 0,30 & 98 & 0,52 & 42 & 0,18 & 90,55 \\
\hline 6 & 99 & 0,30 & 90 & 0,52 & 41 & 0,18 & 83,86 \\
\hline 7 & 91 & 0,30 & 89 & 0,52 & 40 & 0,18 & 80,76 \\
\hline 8 & 81 & 0,30 & 84 & 0,52 & 38 & 0,18 & 74,84 \\
\hline 9 & 75 & 0,30 & 83 & 0,52 & 36 & 0,18 & 72,14 \\
\hline 10 & 45 & 0,30 & 71 & 0,52 & 36 & 0,18 & 56,94 \\
\hline
\end{tabular}


Nilai curah hujan harian maksimum rata-rata berada diantara $56,94 \mathrm{~mm} \mathrm{~s} / \mathrm{d}$ $151,50 \mathrm{~mm}$ yang termasuk dalam kategori curah hujan tinggi. Hasil dari analisa menunjukan karakteritik curah hujan di sekitar wilayah DAS Sei Sikambing memilki potensi yang cukup tinggi untuk terjadinya kondisi banjir. Prediksi curah hujan rata-rata dari 3 stasiun penakar curah hujan diuji distribusi untuk mengetahui tingkat derajat kepercayaan data curah hujan terhadap distribusi curah hujan di dalam cakupan wilayah daerah aliran sungai. Metode uji distribusi yang digunakan dengan uji Smirnov Kolmogorov yang ditampilkan pada Tabel 4.

Tabel 4 Hasil uji distribusi curah hujan harian rata-rata maksimum dengan metode Smirnov Kolmogorov

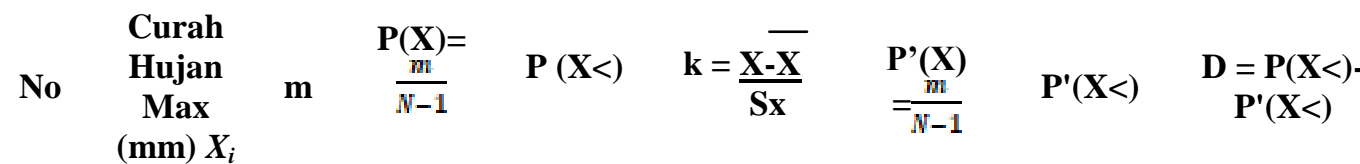

\begin{tabular}{ccccccccc}
\hline 1 & 151,50 & 1 & 0,091 & 0,909 & 2,133 & 0,111 & 0,984 & 0,075 \\
\hline 2 & 124,09 & 2 & 0,182 & 0,818 & 1,133 & 0,222 & 0,871 & 0,053 \\
\hline 3 & 101,43 & 3 & 0,273 & 0,727 & 0,307 & 0,333 & 0,626 & 0,102 \\
\hline 4 & 94,11 & 4 & 0,364 & 0,636 & 0,040 & 0,444 & 0,472 & $\mathbf{0 , 1 6 4}$ \\
\hline 5 & 90,55 & 5 & 0,455 & 0,545 & $-0,090$ & 0,556 & 0,460 & 0,085 \\
\hline 6 & 83,86 & 6 & 0,545 & 0,455 & $-0,334$ & 0,667 & 0,375 & 0,080 \\
\hline 7 & 80,76 & 7 & 0,636 & 0,364 & $-0,447$ & 0,778 & 0,326 & 0,037 \\
\hline 8 & 74,84 & 8 & 0,727 & 0,273 & $-0,663$ & 0,889 & 0,242 & 0,031 \\
\hline 9 & 72,14 & 9 & 0,818 & 0,182 & $-0,762$ & 1,000 & 0,171 & 0,011 \\
\hline 10 & 56,94 & 10 & 0,909 & 0,091 & $-1,316$ & 1,111 & 0,127 & 0,036 \\
\hline
\end{tabular}

Nilai distribusi curah hujan harian maksimum rata-rata Dmax $=0,16$ yang dihitung berdasarkan jumlah data 10 tahun. Nilai distribusi maksimum dilakukan uji distribusi dengan tingkat kepercayaan yang ditampilkan pada Tabel 5.

Tabel 5 Tingkat derajat kepercayaan distribusi curah hujan dengan jumlah data

\begin{tabular}{ccccc}
\multirow{2}{*}{ Jumlah data (n) } & \multicolumn{4}{c}{ Derajat Kepercayaan $\alpha$} \\
\cline { 2 - 5 } & 0,2 & 0,1 & 0,05 & 0,01 \\
\hline 5 & 0,45 & 0,51 & 0,56 & 0,67 \\
\hline 10 & 0,32 & 0,37 & 0,41 & 0,49 \\
\hline 15 & 0,27 & 0,30 & 0,34 & 0,40 \\
\hline 20 & 0,23 & 0,26 & 0,29 & 0,36 \\
\hline 25 & 0,21 & 0,24 & 0,27 & 0,32 \\
\hline 30 & 0,19 & 0,22 & 0,24 & 0,29 \\
\hline 35 & 0,18 & 0,20 & 0,23 & 0,27 \\
\hline 40 & 0,17 & 0,19 & 0,21 & 0,25 \\
\hline 45 & 0,16 & 0,18 & 0,20 & 0,24 \\
\hline 50 & 0,15 & 0,17 & 0,19 & 0,23 \\
\hline $\mathrm{n}>50$ & $1,07 / \mathrm{n}$ & $1,22 / \mathrm{n}$ & $1,36 / \mathrm{n}$ & $1,63 / \mathrm{n}$ \\
\hline
\end{tabular}


Berdasarkan tingkat kepercayaan data untuk jumlah data 10 tahun dengan tingkat kepercayaan paling tinggi $20 \%(0,2)$ nilai distribusi kritis (Dkritis) yaitu 0,32 (Agus, 2010). Syarat uji distribusi dengan data curah hujan rata-rata harian maksimum harus lebih kecil dari distribusi kritis dengan derajat kepercayaan sehingga hasil uji distribusi antara data curah hujan harian maksimum dengan syarat uji distribusi yaitu Dmax $<$ Dkritis $=0,16<0,32$ sehingga nilai data curah hujan harian maksimum rata-rata dari 3 stasiun penakar curah hujan dapat digunakan dalam analisa curah hujan kala ulang. Prediksi curah hujan kala ulang dengan analisa statistik probabilistik dibutuhkan untuk menentukan debit banjir dengan periode kala ulang yang dihitung berdasarkan hasil analisa curah hujan harian maksimum rata-rata. Metode statistik probabilitas yang digunakan dalam analisa curah hujan kala ulang yaitu metode Normal, Log normal, Log person III, dan Gumbel. Hasil analisa curah hujan kala ulang 2 s/d 100 tahun ditampilkan pada Tabel 6 .

Tabel 6 Hasil analisa curah hujan kala ulang 2 s/d 100 tahun DAS Sei Sikambing

\begin{tabular}{lcccccc}
\hline \multirow{2}{*}{ Metode } & \multicolumn{6}{c}{ Curah Hujan Periode Kala Ulang (mm) } \\
\cline { 2 - 7 } & 2 & 5 & 10 & 25 & 50 & 100 \\
\hline Normal & 93,02 & 116,05 & 128,11 & 139,85 & 149,22 & 156,90 \\
\hline Log Normal & 89,72 & 113,41 & 128,22 & 144,47 & 158,92 & 171,83 \\
\hline Log Pearson III & 88,67 & 110,27 & 129,13 & 149,71 & 165,18 & 180,84 \\
\hline Gumbel & 89,28 & 122,34 & 144,23 & 171,89 & 192,41 & 212,78 \\
\hline
\end{tabular}

Nilai curah hujan kala ulang dengan 4 metode diuji berdasarkan beberapa parameter yaitu koefisien variasi, koefisien kurtosis, dan koefisien variasi untuk menentukan nilai curah hujan yang digunakan dalam analisa debit banjir kala ulang. Uji kecocokan distribusi curah hujan kala ulang bertujuan untuk membandingkan hasil analisa curah hujan kala ulang dengan syarat parameter uji distribusi berdasarkan 3 koefisien parameter. Hasil uji kecocokan distribusi curah hujan kala ulang dengan 3 koefisien parameter ditampilkan pada Tabel 7.

Tabel 7 Hasil uji distribusi parameter koefisien statistik distribusi curah hujan kala ulang Das Sei Sikambing

\begin{tabular}{|c|c|c|c|c|c|c|c|c|}
\hline \multirow{2}{*}{$\begin{array}{c}\text { Jenis } \\
\text { Sebaran }\end{array}$} & \multicolumn{3}{|c|}{ Syarat } & \multicolumn{3}{|c|}{ Hasil Perhitungan } & \multicolumn{2}{|c|}{ Perbandingan } \\
\hline & Cs & $\mathbf{C k}$ & $\mathrm{Cv}$ & Cs & $\mathbf{C k}$ & $\mathrm{Cv}$ & Cs & $\mathbf{C k}$ \\
\hline Normal & $=0$ & - & $=3$ & 1,117 & 3,602 & 0,294 & No Ok & No Ok \\
\hline Log Normal & $=3 \mathrm{Cv}$ & - & $=0,6$ & 0,884 & 3,602 & 0,294 & No Ok & No Ok \\
\hline $\begin{array}{c}\text { Log Pearson } \\
\text { III }\end{array}$ & $\neq 0$ & - & $\neq 0$ & 1,117 & 3,602 & 0,294 & Ok & Ok \\
\hline Gumbel & $<1,139$ & $<5.400$ & - & 1,117 & 3,602 & 0,294 & Ok & Ok \\
\hline
\end{tabular}

Berdasarkan dari keempat metode diperoleh bahwasanya koefisien statistik distribusi dengan metode log person III telah memenuhi syarat untuk digunakan dalam perhitungan debit banjir kala ulang 2 s/d 100 tahun. Analisa debit banjir kala ulang dilakukan dengan menggunakan metode Hidrograf Satuan Sintetik Nakayasu berdasarkan data luas catchment area, panjang sungai, dan koefisien 
limpasan. Metode debit banjir rancangan kala ulang Hidrograf Satuan Sintetik Nakayasu diperhitungan berdasarkan waktu puncak banjir (Tp), waktu konsentrasi $(\mathrm{Tg})$, dan waktu surut $\left(\mathrm{T}_{0.3}\right)$ dengan pengaruh besarnya distribusi curah hujan jamjaman (Kurniawan, 2012). Distribusi curah hujan jam-jaman menghasilkan intensitas curah hujan jam-jaman yang dikombinasikan dengan curah hujan periode kala ulang yang menghasilkan debit banjir dengan kala ulangnya. Hasil analisa debit banjir kala ulang 2 s/d 100 tahun DAS Sei Sikambing ditampilkan pada Tabel 8.

Tabel 8 Hasil analisa debit banjir kala ulang 2 s/d 100 tahun Das Sei Sikambing dengan metode HSS Nakayasu

\begin{tabular}{|c|c|c|c|c|c|c|c|}
\hline \multirow{3}{*}{$\begin{array}{l}\text { Waktu } \\
\text { (jam) }\end{array}$} & \multirow{3}{*}{$\begin{array}{c}\text { Unit Hidrograf } \\
\mathbf{Q t} \\
\left(\mathbf{m}^{3} / \mathrm{dt}\right)\end{array}$} & \multicolumn{6}{|c|}{ Grand Total Debit (m3/d) } \\
\hline & & \multicolumn{6}{|c|}{ Kala Ulang (Tahun) } \\
\hline & & 2 & 5 & 10 & 25 & 50 & 100 \\
\hline 0.00 & 0,000 & 0,70 & 0,70 & 0,70 & 0,70 & 0,70 & 0,70 \\
\hline 1,00 & 0,149 & 13,93 & 17,16 & 19,97 & 23,04 & 25,35 & 27,69 \\
\hline 2,00 & 0,788 & 70,54 & 87,54 & 102,40 & 118,61 & 130,79 & 143,13 \\
\hline 2,55 & 1,411 & 125,81 & 156,28 & 182,90 & 211,94 & 233,76 & 255,86 \\
\hline 3,00 & 1,191 & 106,31 & 132,03 & 154,51 & 179,02 & 197,44 & 216,09 \\
\hline 4,00 & 0,823 & 73,70 & 91,48 & 107,01 & 123,96 & 136,69 & 149,58 \\
\hline 5,00 & 0,569 & 51,16 & 63,45 & 74,19 & 85,90 & 94,70 & 103,61 \\
\hline 5,81 & 0,422 & 38,12 & 47,23 & 55,19 & 63,87 & 70,40 & 77,00 \\
\hline 6,00 & 0,403 & 36,42 & 45,11 & 52,71 & 61,00 & 67,23 & 73,54 \\
\hline 7,00 & 0,315 & 28,62 & 35,42 & 41,36 & 47,84 & 52,71 & 57,64 \\
\hline 8,00 & 0,246 & 22,53 & 27,84 & 32,49 & 37,55 & 41,36 & 45,22 \\
\hline 9,00 & 0,192 & 17,77 & 21,92 & 25,55 & 29,51 & 32,49 & 35,50 \\
\hline 10,00 & 0,150 & 14,04 & 17,29 & 20,13 & 23,22 & 25,55 & 27,91 \\
\hline 10,70 & 0,127 & 11,93 & 14,66 & 17,05 & 19,66 & 21,62 & 23,60 \\
\hline
\end{tabular}

Debit banjir kala ulang dengan metode Hidrograf Satuan Sintetik Nakayasu menghasilkan debit puncak yang terjadi pada waktu puncak banjir 2,55 jam. Besar debit banjir kala ulang $2 \mathrm{~s} / \mathrm{d} 100$ tahun berada diantara $125,81 \mathrm{~m}^{3} / \mathrm{det} \mathrm{s} / \mathrm{d} 255,86$ $\mathrm{m}^{3} /$ det. Berdasarkan hasil analisa curah hujan kala ulang yang dibandingkan dengan data curah hujan harian maksimum menunjukan potensi terjadinya debit banjir yang sesuai dengan aktual di lapangan adalah debit banjir dengan periode kala ulang 25 tahun. Analisa tinggi muka air banjir dihitung berdasarkan debit banjir kala ulang 25 tahun.

\subsection{Analisa Hidraulika}

Analisa hidraulika dalam penelitian ini bertujuan untuk mengetahui potensi tinggi muka air banjir di penampang Sungai Sikambing. Tinggi muka banjir dianalisa menggunakan software HECRAS dengan data profil sungai baik itu penampang memanjang dan melintang sungai (Satya, 2014). Koefisien kekasaran saluran atau sungai menjadi salah satu data penting yang dibutuhkan dalam analisa tinggi muka air banjir yang diperhitungkan berdasarkan jenis material penampang sungai seperti material tanah atau beton. Nilai koefisien kekasaran saluran atau sungai diperoleh berdasarkan formula Manning atau Strickler yang telah dilakukan penelitian sebelumnya terhadap jenis material penampang sungai. 
Hasil analisa tinggi muka air banjir di tiap bagian penampang Sungai Sikambing yang mewaliki bagian hulu, tengah, dan hilir yang dijelaskan sebagai berikut.

\section{A. Analisa Tinggi Muka Air Banjir Penampang Memanjang Sungai}

Analisa tinggi muka air banjir penampang memanjang Sungai Sikambing diperhitungkan dimulai dari bagian hulu sampai hilir sungai dengan menggunakan software HECRAS (Wigati, 2018). Profil penampang memanjang sungai diperoleh dari hasil pengukuran di lapangan dengan panjang sungai mencapai $18,73 \mathrm{~km}$. Karakteristik profil memanjang Sungai Sikambing termasuk dalam kategori Sungai Meander dengan alur berkelok yang hampir menyerupai bentuk "S" yang ditampilkan pada Gambar 4.

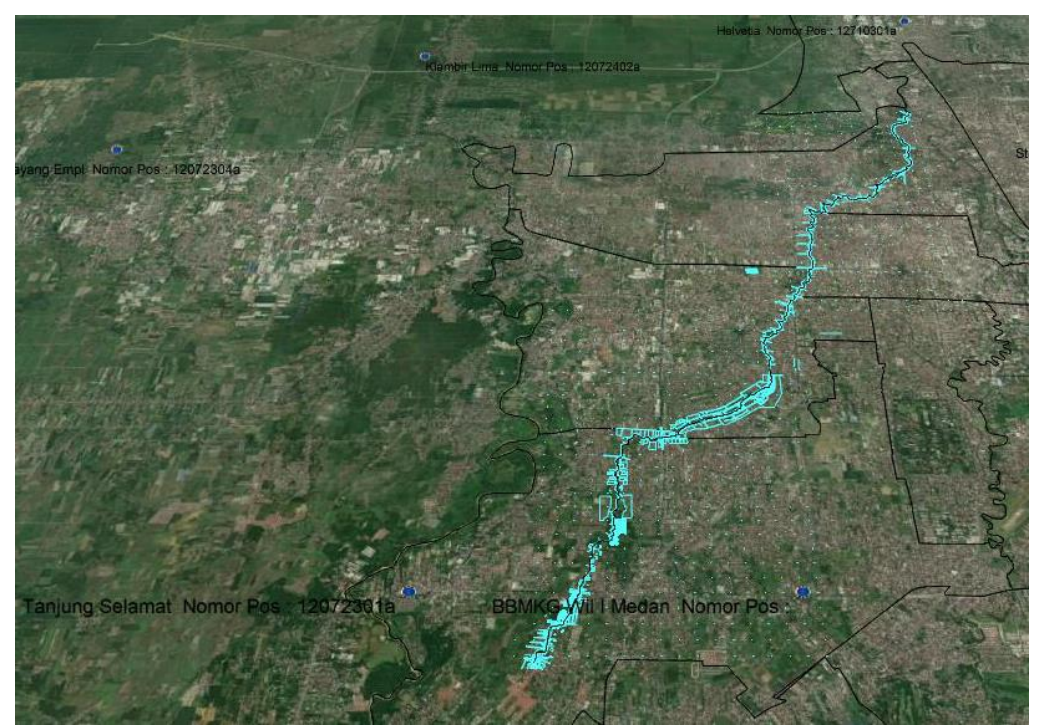

Gambar 4 Bentuk karakteristik penampang sungai Sikambing

Hasil analisa tinggi muka air banjir penampang memanjang (Long Section) Sungai Sikambing ditampilkan pada Gambar 5.

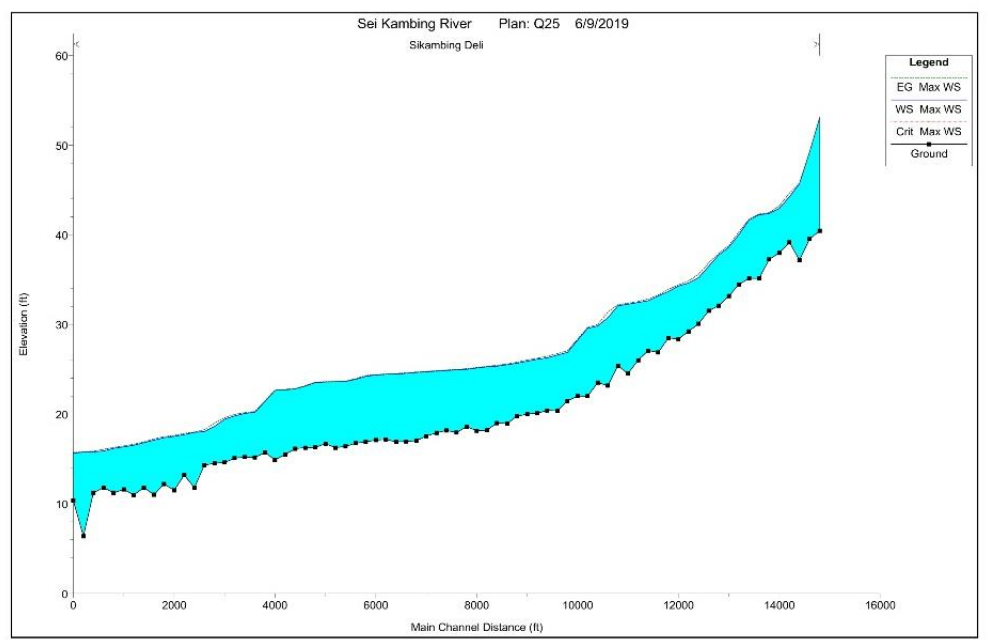

Gambar 5 Tinggi muka air banjir periode kala ulang 25 tahun Sungai Sikambing

Studi Pemetaan Daerah Genangan Banjir Das Sei Sikambing Dengan Sistem Informasi Geografis - Asril Zevri 
Hasil analisa tinggi muka air banjir Sungai Sikambing dari bagian hulu sampai hilir memiliki variasi yang berbeda dikarenakan elevasi dasar penampang sungai memiliki ketinggian yang berbeda yang disebut dengan aliran tidak mantap atau Unsteady Flow. Ketinggian elevasi bagian hulu berada di ketinggian $40 \mathrm{~m}$ dan hilir berada di ketinggian $10 \mathrm{~m}$ di atas permukaan laut. Tinggi muka air banjir berada diantara $2 \mathrm{~s} / \mathrm{d} 4 \mathrm{~m}$ di atas permukaan tebing penampang melintang sungai yang dijelaskan sebagai berikut.

\section{B. Analisa Tinggi Muka Air Banjir Penampang Melintang Sungai}

Analisa tinggi muka air banjir penampang melintang sungai dengan Software HECRAS di bagian hulu, tengah, dan hilir memilki ketinggian yang berbeda dikarenakan memiliki dimensi penampang melintang yang berbeda. Dimensi penampang melintang yang berpengaruh yaitu lebar dasar, kemiringan talud sungai, dan lebar atas penampang melintang sungai. Hasil analisa tinggi muka air banjir penampang melintang sungai dijelaskan sebagai berikut.

\section{Tinggi Muka Air Banjir di Penampang Melintang Hulu}

Kondisi dimensi penampang melintang bagian hulu terdiri dari lebar bawah yang mencapai $4 \mathrm{~m}$ dan lebar atas $12 \mathrm{~m}$ dengan material berbentuk tanah. Elevasi tebing sungai di bagian hulu +39 m dengan Elevasi muka air banjir $+42 \mathrm{~m}$ sehingga tinggi muka air banjir mencapai $3.5 \mathrm{~m}$ dari tebing sungai yang ditampilkan pada Gambar 6.

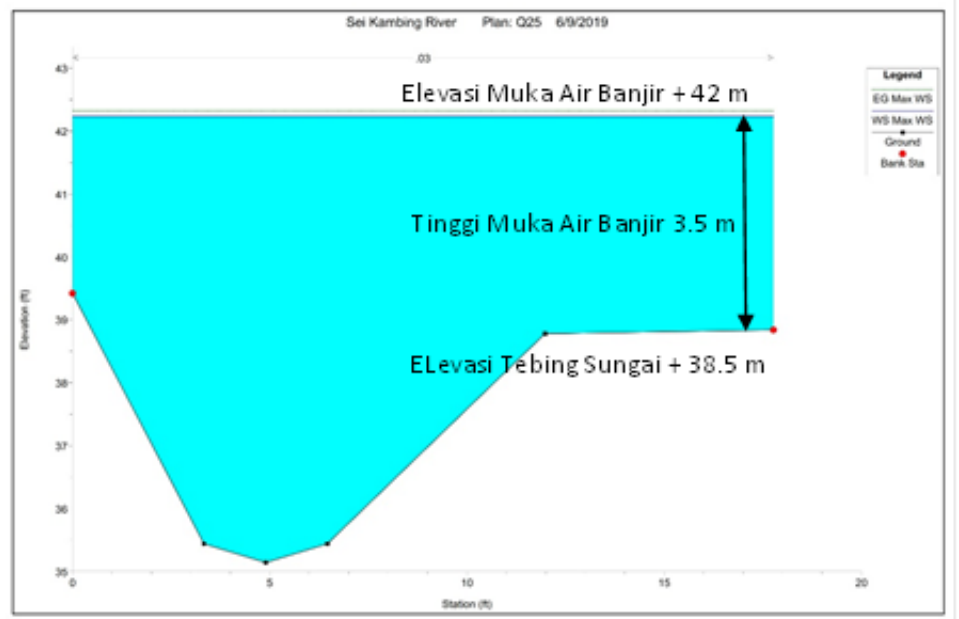

Gambar 6 Tinggi muka air banjir penampang melintang hulu Sungai

Sikambing

\section{Tinggi Muka Air Banjir di Penampang Melintang Tengah}

Kondisi dimensi penampang melintang bagian tengah terdiri dari lebar bawah yang mencapai $8 \mathrm{~m}$ dan lebar atas $18 \mathrm{~m}$ dengan material berbentuk tanah. Elevasi tebing sungai di bagian hulu $+21 \mathrm{~m}$ dengan Elevasi muka air banjir $+24.7 \mathrm{~m}$ sehingga tinggi muka air banjir mencapai $3.7 \mathrm{~m}$ dari tebing sungai yang ditampilkan pada Gambar 7 . 


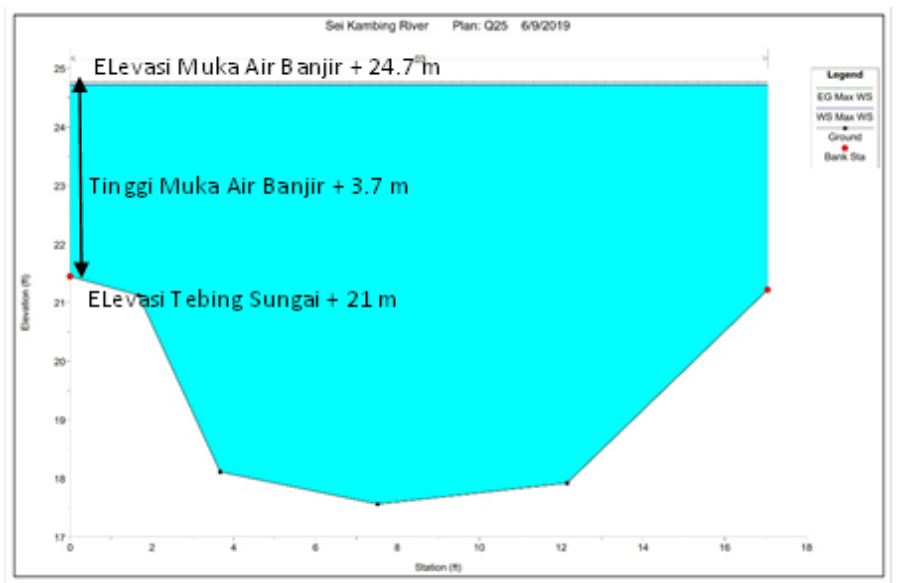

Gambar 7 Tinggi muka air banjir penampang melintang tengah Sungai Sikambing

\section{Tinggi Muka Air Banjir di Penampang Melintang Hilir}

Kondisi dimensi penampang melintang bagian hilir terdiri dari lebar bawah yang mencapai $6 \mathrm{~m}$ dan lebar atas $14 \mathrm{~m}$ dengan material berbentuk tanah. Elevasi tebing sungai di bagian hulu $+18 \mathrm{~m}$ dengan Elevasi muka air banjir $+19.7 \mathrm{~m}$ sehingga tinggi muka air banjir mencapai $1.7 \mathrm{~m}$ dari tebing sungai yang ditampilkan pada Gambar 8.

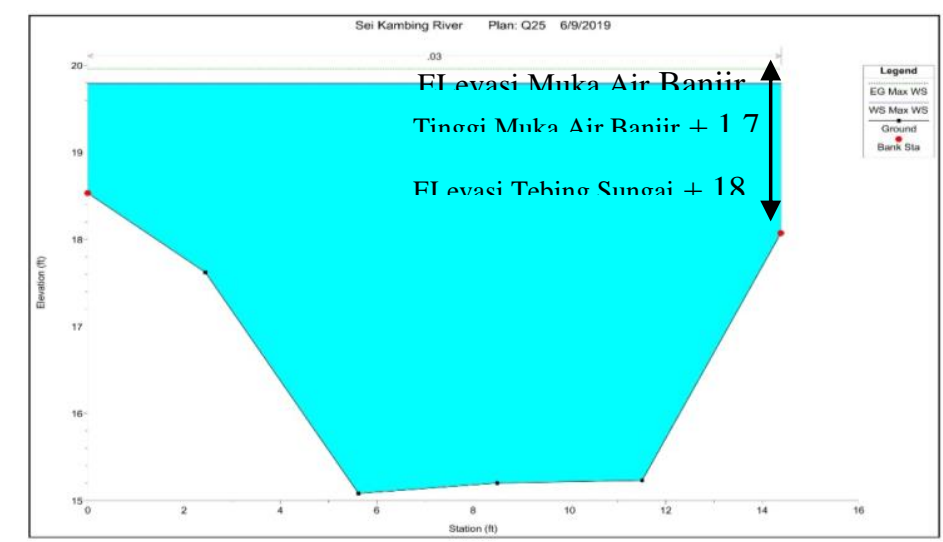

Gambar 8 Tinggi muka air banjir penampang melintang hilir Sungai

Sikambing

\subsection{Analisa Pemetaan Daerah Genangan Banjir DAS Sikambing}

Analisa pemetaan daerah genangan banjir DAS Sikambing dilakukan dengan menggunakan Sistem Informasi Geografis (SIG). Sistem Informasi Geografis adalah sistem komputer yang digunakan untuk mengumpulkan, memeriksa, mengintegrasikan, dan menganalisa informasi-informasi yang berhubungan dengan permukaan bumi. Perkembangan Sistem Informasi Geografis terhadap sumber daya air salah satunya dengan mengidentifikasi pembagian daerah aliran sungai, jaringan alur sungai, kemiringan lereng, dan kondisi geometri sungai (Ginting, 2010). Hasil atau output dari analisa Sistem Informasi Geografis secara umum ditampilkan dalam bentuk peta. Integrasi antara peta topografi, peta Daerah Aliran Sungai, peta Administrative, peta profil sungai 
dengan tinggi muka air banjir yang dianalisa dengan software HECRAS dapat memberikan potensi daerah genangan banjir DAS Sikambing (Zevri, 2017). Hasil pemetaan potensi daerah genangan banjir DAS Sikambing ditampilkan pada Gambar 9.

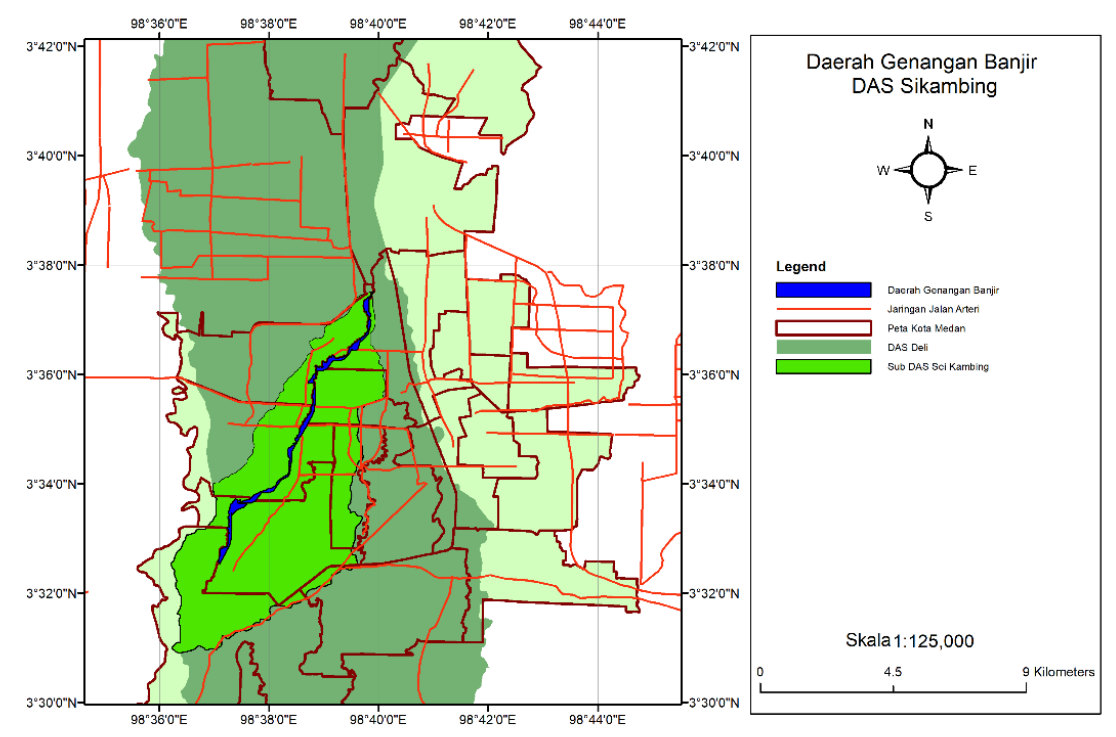

Gambar 9 Peta daerah genangan banjir Das Sei Sikambing

Hasil analisa pemetaan daerah genangan banjir DAS Sikambing dengan Sistem Informasi Geografis memberikan informasi luas daerah genangan banjir DAS Sikambing mencapai $1,19 \mathrm{Km}^{2}$ yang mencakup dari hulu sampai hilir. Dampak daerah genangan banjir mengakibatkan beberapa daerah kecamatan di Kota Medan terkena banjir dengan luasan genangan yang berbeda. Luasan dampak genangan banjir DAS Sikambing terhadap beberapa kecamatan di Kota Medan ditampilkan pada Tabel 9.

Tabel 9 Lokasi kecamatan terkena dampak daerah genangan banjir DAS Sikambing

\begin{tabular}{ccc}
\hline \multirow{2}{*}{ No } & Kecamatan & $\begin{array}{c}\text { Luas } \\
\text { Genangan }\end{array}$ \\
\cline { 3 - 3 } & & Km2 \\
\hline 1 & Medan Selayang & 0,42 \\
\hline 2 & Medan Sunggal & 0,32 \\
\hline 3 & Medan Petisah & 0,04 \\
\hline 4 & Medan Helvetia & 0,05 \\
\hline 5 & Medan Barat & 0,36 \\
\hline & Total & 1,19 \\
\hline
\end{tabular}

Hasil analisa pemetaan daerah genangan banjir menunjukan lokasi kecamatan Medan Selayang menjadi lokasi daerah genangan banjir yang terluas dan Kecamatan Medan Barat. 


\section{Kesimpulan dan Saran}

\subsection{Kesimpulan}

Hasil penelitian menunjukan debit banjir kala ulang DAS Sikambing dengan periode kala ulang 25 tahun $211,94 \mathrm{~m}^{3} /$ det menimbulkan tinggi muka air banjir DAS Sikambing berada diantara $1,7 \mathrm{~m} \mathrm{~s} / \mathrm{d} 3,7 \mathrm{~m}$. Analisa pemetaan Daerah genangan banjir DAS Sei Sikambing dengan Sistem Informasi Geografis memberikan informasi luasan daerah genangan banjir mencapai $1,19 \mathrm{Km}^{2}$ yang mengakibatkan dampak banjir terhadap 5 kecamatan di Kota Medan yaitu Kecamatan Medan Selayang mencapai luas genangan banjir 0,42 $\mathrm{km}^{2}$, Medan Sunggal mencapai luas genangan banjir $0,32 \mathrm{~km}^{2}$, Medan Petisah mencapai luas genangan banjir $0,04 \mathrm{~km}^{2}$, Medan Helvetia mencapai luas genangan $0,05 \mathrm{~km}^{2}$, dan Medan Barat mencapai luas genangan banjir $0,36 \mathrm{~km}^{2}$.

\subsection{Saran}

Berdasarkan kesimpulan dapat diberikan solusi atau saran dalam penanggulangan banjir di Kota Medan akibat luapan banjir DAS Sikambing dengan metode struktural yaitu pembangunan tanggul dan normalisasi sungai di sepanjang penampang sungai baik itu bagian hulu, tengah, dan hilir.

\section{Daftar Kepustakaan}

Agus, I. 2010. Penentuan Jenis Distribusi Dan Uji Kesesuaian Smirnov Kolmogorov Data Hujan Das Taratak Timbulun Kabupaten Pesisir Selatan. Jurnal Rekayasa Sipil. Politeknik Negeri Padang.

BPBD Kota Binjai. 2018. Laporan Dampak Kerugian Banjir Kota Medan: BPBD Kota Medan.

Cahyono, T. 2016. Pemodelan Spasial Untuk Pembuatan Peta Rawan Banjir dan Peta Tingkat Risiko Banjir Bengawan Solo di Kota Surakarta. Jurnal Geografi Indonesia. Vol. 29. No. 1. Hal - 60-72. Fakultas Geografi. UGM, Yogyakarta.

Ginting S. H. 2010. Analisis Profil Muka Air Sungai Dengan HEC-RAS. Bandung. Balai Hidrologi dan Tata Air Puslitbang SDA.

Ginting S. H. 2010. Pemetaan Dataran Banjir Dengan HEC-GEORAS dan GIS. Bandung. Balai Hidrologi dan Tata Air Puslitbang SDA.

Kurniawan, A. 2012. Analisis Debit Banjir Rancangan Sungai Babura di Hilir Kawasan Kampus USU. Tugas Akhir Sksripsi Bidang Studi Teknik Sumber Daya Air USU, Medan.

Marlena, N. 2010. Analisis Risiko Banjir Terhadap Produktivitas Padi Menggunakan Teknik Penginderaan Jauh dan Sistem Informasi Geografis di DAS Dengkeng Kabupaten Klaten Jawa Tengah. Tesis. Yogyakarta. Pascasarjana. UGM.

Mulia, A.P. dan Zevri, A. 2017. A Study on the Estimation of Flood Damage in Medan City MATEC Web of Conferences 138. 
Satya, T.M. 2014. Studi Normalisasi Sungai Sampean Sebagai Upaya Pengendalian Banjir. Jurnal Teknik Pengairan Universitas Brawijaya, Malang.

U.S Army Corps of Engineers - Hydrologic Engineering Center (HEC). 2001. Hydraulic Reference Manual HEC-RAS 3.1.3. California: U.S. Army Corps of Engineers.

Wigati, R. dkk. 2018. Normalisasi Sungai Ciliwung Menggunakan Program HECRAS 4.1 (Studi Kasus Cililitan - Bidara Cina). Jurnal Fondasi Vol 5. No.1. Teknik Sipil Universitas Sultan Agung Tirtayasa, Malang.

Zevri, A. 2014. Analisis Potensi Resiko Banjir pada DAS yang Mencakup Kota Medan dengan Sistem Informasi Geografis. Tesis Master Prodi S2 Teknik Sipil USU, Medan.

Zevri, A. 2017. Studi Potensi Derah Genangan Banjir Das Belawan Dengan Sistem Informasi Geografis. Prosiding: Seminar Nasional Aplikasi Teknologi Prasarana Wilayah X (ATPW) ITS, 73-82. 